\title{
Use of the Existing Sheilded Cells Melter for CST Vitrification
}

by

J. R. Harbour

Westinghouse Savannah River Company

Savannah River Site

Aiken, South Carolina 29808

M. K. Andrews

This paper was prepared in connection with work done under the above contract number with the U.S. Department of Energy. By acceptance of this paper, the publisher and/or recipient acknowledges the U. S. Government's right to retain a nonexclusive, royalty-free license in and to any copyright covering this paper, along with the right to reproduce and to authorize others to reproduce all or part of the copyrighted paper. 


\section{DISCLAIMER}

This report was prepared as an account of work sponsored by an agency of the United States Government. Neither the United States Government nor any agency thereof, nor any of their employees, makes any warranty, express or implied, or assumes any legal liability or responsibility for the accuracy, completeness, or usefulness of any information, apparatus, product, or process disclosed, or represents that its use would not infringe privately owned rights. Reference herein to any specific commercial product, process, or service by trade name, trademark, manufacturer, or otherwise does not necessarily constitute or imply its endorsement, recommendation, or favoring by the United States Government or any agency thereof. The views and opinions of authors expressed herein do not necessarily state or reflect those of the United States Government or any agency thereof.

This report has been reproduced directly from the best available copy.

Available to DOE and DOE contractors from the Office of Scientific and Technical Information, P. O. Box 62, Oak Ridge, TN 37831; prices available from (423) 576-8401.

Available to the public from the National Technical Information Service, U. S. Department of Commerce, 5285 Port Royal Road, Springfield, VA 22161. 


\section{DISCLAIMER}

Portions of this document may be illegible electronic image products. Images are produced from the best available original document. 


\title{
WESTINGHOUSE SAVANNAH RIVER COMPANY \\ SAVANNAH RIVER TECHNOLOGY CENTER
}

WSRC-RP-96-593

\section{USE OF THE EXISTINGSHIELDED CELLS MELTER FOR CST VITRIFICATION (U)}

\author{
J. R. Harbour and M. K. Andrews \\ Westinghouse Savannah River Company \\ Aiken, S. C. 29808
}

\section{INTRODUCTION}

Oak Ridge National Laboratory (ORNL) and SRTC are participating in a joint project in which supernate waste from the Melton Valley Storage Tanks at Oak Ridge (OR) will be treated by passage through a crystalline silicotitanate (CST) ion exchange medium ${ }^{1}$. The CST was designed to sorb cesium, the primary radionuclide (Cs-137) in the supernate of the Melton Valley tanks. A smaller amount of strontium will also be sorbed. The loaded sorbent will then be shipped to SRTC where it will be mixed with glass formers and fed as an aqueous slurry to a joule-heated melter within the SRTC Shielded Cells. The molten glass $\left(\sim 1150^{\circ} \mathrm{C}\right)$ will be poured into $500 \mathrm{~mL}$ stainless steel beakers which in turn will be placed in 30 gallon drums for shipment to and disposal at the Nevada Test Site (NTS). This paper focuses on the requirements necessary for disposal of the vitrified CST at NTS. This work is funded by the Tank Focus Area with additional funding from EM-30 at OR.

A reduction in scope is currently under consideration for the vitrification demonstration. This change in scope would reduce the number of drums sent to SRTC from seven to one. The amount of CST that would be vitrified in this case is $\sim 38 \mathrm{Kg}$. If this scope change is realized, then the vitrified CST in the $500 \mathrm{~mL}$ beakers will be disposed of at Savannah River Site (SRS). The results presented in this report will also be useful if the vitrified waste remains at SRS.

The Shielded Cells Melter currently contains glass produced during a 1995 DWPF demonstration campaign. That campaign incorporated radioactive Tank 51 sludge into a DWPF borrosilicate glass. The Tank 51 campaign in the Shielded Cells Melter was preceded with a flushing of the melter using non-radioactive glass. This flushing was preceded by a different Tank 51 campaign again using borosilicate glass. The 1995 Tank 51 campaign and the melter flushing each used less than one melter volume of material. This implies that the glass currently in the melter is a composite of glass from both Tank 51 campaigns and from melter flushing. If the vitrified CST will be shipped to NTS, the radioactive glass currently in the melter must be removed prior to the CST vitrification demonstration in order to avoid commingling of the waste.

This report (1) estimates the concentrations of the radioactive and RCRA hazardous components of the glass now contained in the Shielded Cells melter, (2) presents the requirements for displacing the existing glass with non-radioactive glass to ensure that radionuclide and RCRA metal levels are below the Waste Acceptance Criteria (WAC) limits set by NTS, (3) identifies the risks associated with a melter flushing strategy and (4) considers the alternative of installing a new melter within the Shielded Cells. 


\section{STATUS OF MELTER}

The melter within the Shielded Cells contains $\sim 10 \mathrm{Kg}$ of molten glass at $\sim 1150^{\circ} \mathrm{C}$. Between campaigns the normal operating procedure is to maintain the melter at $1050^{\circ} \mathrm{C}$ with a full load of glass.

Radioactive Tank 51 sludge $^{2}$ was used in the last melter campaign, which produced $9.1 \mathrm{Kg}$ of glass. This Tank 51 campaign was preceded with a $6.95 \mathrm{Kg}$ flushing of the melter using nonradioactive glass frit. This flushing was preceded by an earlier Tank 51 campaign, using $~ 31$ $\mathrm{Kg}$ of borosilicate glass. Since the nonradioactive glass frit did not contain radionuclides or RCRA metals, the only source for introduction of these constituents is Tank 51 sludge.

Material flow through the melter can range from plug flow to a continuously stirred tank flow. For this report the more conservative material flow, continuously stirred tank flow, was used to estimate the current constituents within the melter. This approach implies that the waste is composed of $\sim 80 \%$ radioactive waste glass (containing $\sim 25$ wt $\%$ Tank 51 sludge) and $\sim 20 \%$ nonradioactive glass. A conservative approach was taken by assuming that the melter currently contains $100 \%$ radioactive waste glass with a $25 \mathrm{wt} \%$ loading of Tank 51 sludge.

\section{RADIONUCLIDE INVENTORY}

The results of radionuclide analyses are presented in two groups. The first group lists transuranic waste, and the second lists the remaining radionuclides.

\section{Group 1. Transuranics.}

The NTS definition of transuranic waste is:

TRANSURANIC (TRU) WASTE: Radioactive waste containing alpha emitting radionuclides having an atomic number greater than 92, and half-lives greater than 20 years, in concentrations greater than $100 \mathrm{nCi} / \mathrm{g}$.

Table 1 lists the transuranics (including $\mathrm{Cm}-244$, even though it has a half life of 18.1 years) present in washed Tank 51 siudge. ${ }^{2}$ This Table also contains the concentrations of transuranics present in the waste glass (assuming $25 \mathrm{wt} \%$ Tank 51 sludge).

TABLE 1 - Alpha Emitting Transuranic Concentrations Present in Tank 51 Sludge (washed and dried) and in the Borosilicate Glass

\begin{tabular}{|c|c|c|c|}
\hline Radionuclide & $\begin{array}{c}\text { Half-Life } \\
\text { years }\end{array}$ & $\begin{array}{c}\text { Tank } 51 \\
\mathrm{nCi} / \mathrm{g}\end{array}$ & $\begin{array}{l}\text { Glass } \\
\mathrm{nCi} / \mathrm{g}\end{array}$ \\
\hline $\mathrm{Np}-237$ & $2.1 \mathrm{E}+06$ & $1.4 \mathrm{E}+01$ & $3.5 \mathrm{E}+00$ \\
\hline $\mathrm{Pu}-238$ & $8.8 \mathrm{E}+01$ & $1.4 \mathrm{E}+05$ & $3.5 \mathrm{E}+04$ \\
\hline $\mathrm{Pu}-239$ & $2.4 \mathrm{E}+04$ & $6.9 \mathrm{E}+03$ & $1.7 \mathrm{E}+03$ \\
\hline $\mathrm{Pu}-240$ & $6.6 E+03$ & $1.8 \mathrm{E}+03$ & $4.5 \mathrm{E}+02$ \\
\hline $\mathrm{Pu}-242$ & $3.7 \mathrm{E}+05$ & $1.6 \mathrm{E}+00$ & $4.0 \mathrm{E}-01$ \\
\hline Am-241 & $4.3 \mathrm{E}+02$ & $6.2 E+03$ & $1.6 \mathrm{E}+03$ \\
\hline Am-243 & $7.4 \mathrm{E}+03$ & $3.8 \mathrm{E}+01$ & $1.0 \mathrm{E}+01$ \\
\hline $\mathrm{Cm}-244$ & 1.8.E+01 & $1.2 \mathrm{E}+04$ & $3.0 \mathrm{E}+03$ \\
\hline
\end{tabular}


The total alpha for transuranics in the glass listed is $\sim 42,000 \mathrm{nCi} / \mathrm{g}$. The NTS requirement limits the TRU component of the waste to less than $100 \mathrm{nCi} / \mathrm{g}$. In order to ensure that this limit is not exceeded, an operational limit of $\sim 50 \mathrm{nCi} / \mathrm{g}$ is proposed. To achieve the proposed operational limit, the glass in the melter must be displaced by the nonradioactive frit such that the TRU radionuclide concentration is reduced by a factor of 840 . That is, $99.88 \%$ of the radionuclides must be removed prior to start of the CST vitrification demonstration. A conservative approach is to require a reduction of the TRU components by a factor of 1000 .

\section{Group 2. Other Radionuclides.}

The concentrations for the remaining radionuclides ${ }^{2}$ in the washed Tank 51 sludge and in the glass are presented in Table 2. (The radionuclide content in $\mathrm{Ci} / \mathrm{Kg}$ was converted to $\mathrm{Ci} / \mathrm{m}^{3}$ using a glass density of $2.7 \mathrm{~g} / \mathrm{cc}$.) These radionuclides emit primarily beta-gamma radiation. For purposes of the calculations, it is conservatively estimated $100 \%$ of the elements listed here are present in the glass (at $25 \%$ waste loading) within the Shielded Cells Melter.

TABLE 2 - Beta-Gamma Emitting Radionuclide Concentrations in Washed Tank 51 Sludge and in DWPF Glass

\begin{tabular}{|c|c|c|c|}
\hline & Sludge & Glass & Glass \\
\hline Radionuclide & $\mathrm{Ci} / \mathrm{kg}$ & $\mathrm{Ci} / \mathrm{kg}$ & $\mathrm{Ci} / \mathrm{m}^{3}$ \\
\hline $\mathrm{Ni}-59$ & $5.40 \mathrm{E}-05$ & $1.40 \mathrm{E}-05$ & $2.70 \mathrm{E}-03$ \\
\hline $\mathrm{Ni}-63$ & $9.60 \mathrm{E}-03$ & $2.40 \mathrm{E}-03$ & $6.50 \mathrm{E}-00$ \\
\hline $\mathrm{Se}-79$ & $2.20 \mathrm{E}-05$ & $5.00 \mathrm{E}-06$ & $1.40 \mathrm{E}-01$ \\
\hline Sr-90 & $6.40 \mathrm{E}-01$ & $1.60 \mathrm{E}-01$ & $4.32 \mathrm{E}+02$ \\
\hline $\mathrm{Zr}-93$ & $5.40 \mathrm{E}-05$ & $1.35 \mathrm{E}-05$ & $3.65 \mathrm{E}-02$ \\
\hline $\mathrm{Nb}-93 \mathrm{~m}$ & $3.10 \mathrm{E}-05$ & $7.75 \mathrm{E}-06$ & $2.10 \mathrm{E}-02$ \\
\hline Tc-99 & $2.20 \mathrm{E}-04$ & $5.50 \mathrm{E}-05$ & $1.50 \mathrm{E}-01$ \\
\hline Pd-107 & $3.80 \mathrm{E}-07$ & $9.50 \mathrm{E}-08$ & $2.60 \mathrm{E}-04$ \\
\hline Sn-126 & $6.50 \mathrm{E}-06$ & $1.63 \mathrm{E}-06$ & $4.40 \mathrm{E}-03$ \\
\hline Cs-135 & $2.50 \mathrm{E}-07$ & $6.25 \mathrm{E}-08$ & $1.70 \mathrm{E}-04$ \\
\hline Cs-137 & $6.30 \mathrm{E}-02$ & $1.60 \mathrm{E}-02$ & $4.32 \mathrm{E}+01$ \\
\hline $\mathrm{Sm}-151$ & $1.20 \mathrm{E}-02$ & $3.00 \mathrm{E}-03$ & $8.10 \mathrm{E}+00$ \\
\hline Th-230 & $4.10 \mathrm{E}-08$ & $1.03 \mathrm{E}-08$ & $2.80 \mathrm{E}-05$ \\
\hline $\mathrm{U}-234$ & $2.50 \mathrm{E}-05$ & $6.25 \mathrm{E}-06$ & $1.70 \mathrm{E}-02$ \\
\hline $\mathrm{U}-238$ & $1.10 \mathrm{E}-05$ & $2.75 \mathrm{E}-06$ & $7.40 \mathrm{E}-03$ \\
\hline
\end{tabular}

The contribution of the beta-gamma emitters present in the Tank 51 glass to the total radioactivity of the CST glass will be small. The removal of $99.9 \%$ of the radionuclides (as a result of the 1000 fold reduction for TRU components) would leave $\sim 0.4 \mathrm{Ci} / \mathrm{m}^{3}$ of Sr-90, the major radionuclide. This value is insignificant relative to the Class $C$ limit of $4600 \mathrm{Ci} / \mathrm{m}^{3}$.

\section{RCRA METAL CONCENTRATIONS}

The glass within the melter contains RCRA metals from the Tank 51 sludge. ${ }^{2}$ Displacement of the current waste glass with a characteristically non-hazardous (from a RCRA point of view) glass frit will reduce the RCRA metals. The estimated RCRA metal concentrations currently in 
the melter are listed in Table 3. (As with the radionuclides, an assumption was made that the melter contains waste glass with a $25 \mathrm{wt} \%$ loading of Tank 51 sludge). These values were obtained by dissolution and analysis of the vitrified Tank 51 SME product.

TABLE 3 - RCRA Metals Present in the SME Product for the 1995 Washed Tank 51 Sludge Campaign

Metal
\begin{tabular}{|l|c|c|c|}
\multicolumn{2}{c}{$\begin{array}{c}\text { Concentration in Glass } \\
\text { wt } \%\end{array}$} & $\begin{array}{c}\text { Regulatory } \\
\text { Limit (ppm) }\end{array}$ \\
\hline Barium & 0.012 & 120 & 100 \\
\hline Cadmium & 0.037 & 370 & 1 \\
\hline Chromium & 0.196 & 1960 & 5 \\
\hline Mercury & 0 & 0 & 0.2 \\
\hline Silver & 0 & 0 & 5 \\
\hline Lead & 0.05 & 500 & 5 \\
\hline
\end{tabular}

The glass in the melter must be displaced with a non-radioactive, RCRA metal-free glass, such that the worst case metal (chromium) is reduced below the regulatory limit of $5 \mathrm{ppm}$. This will lead to a new glass within the melter which is characteristically non-hazardous (RCRA). To reach the $5 \mathrm{ppm}$ level, the displacement with frit must reduce the level of chromium by a factor of 392. In order to ensure that this limit is not exceeded, an operational limit of $2.5 \mathrm{ppm}$ is proposed. This requires that the factor of 392 be doubled to 784 . Therefore, a reduction by a factor of 1000 (path forward for the transuranics) will reduce the RCRA metal levels below the threshold values of characteristically hảzardous materials.

\section{OVERALL DISPLACEMENT}

The displacement of the glass currently in the melter by a new nonradioactive glass frit must reduce radionuclides and RCRA metals to levels that meet the NTS WAC if the vitrified CST will be shipped to NTS. To achieve this, both the transuranics and RCRA metals must be reduced to concentrations that are approximately 1000 times less than currently in the glass within the melter. The value of 1000 , although conservative, will be used in the discussions that follow.

\section{MELTER FLUSHING}

Glass frit can be fed to the melter to displace the existing waste. The amount of frit that must be introduced and processed depends upon the mechanism of mixing within the melter. If the two extremes of mixing are plug flow and continuously stirred tank flow, then the continuously stirred tank model is more conservative. If one melter turnover (defined as the melter capacity, which in this case is $\sim 10 \mathrm{~kg}$ ) displaces $50 \%$ of the radionuclides and RCRA metals, then 10 meiter turnovers will be required to reduce the radionuclides and RCRA metals to acceptable levels. The actual displacement by one melter volume is greater than $60 \%$ for continuously stirred tank mixing. Therefore, the $50 \%$ assumption can be considered conservative. 
A potential risk with flushing is that regions within the melter where convection and mixing may be slower (including the wall/glass interface) could prolong the release of radionuclides and RCRA metals. If dried slurry/glass adheres either to the refractory above the molten glass line, the melter lid, or the electrodes, there is also the possibility that pieces of this glass or dried slurry could break free from these locations and enter the melt pool.

An estimate has been made for the amount of waste glass (containing $25 \mathrm{wt} \%$ Tank 51 sludge) which must be introduced into the melt to cause radionuclides or RCRA metal limits to be exceeded. Using the concentration level of Pu-238 in the glass, $\sim 25$ grams of Tank 51 containing glass, which if thoroughly and instantly mixed with the melt pool, would cause the entire pool to reach the TRU limit of $100 \mathrm{nCi} / \mathrm{g}$. Since the density of glass is $\sim 2.5$, this corresponds to $\sim 10 \mathrm{~mL}$ of glass.

The type of non-radioactive glass used to flush the melter is also important. Certain glasses may more readily remove or displace the current glass in the melter. However, the glass in the melter must be compatible with the feed introduced during the vitrification of the CST sorbent. The preferred way of accomplishing this is to use a frit that is identical to the expected CST waste glass formulation (without radionuclides).

During the process of flushing the melter, samples will be taken from the glass pour stream. These samples will be dissolved and analyzed for RCRA metals and radionuclides to determine the efficiency of the flushing. The actual number of melter turnovers required will not be based on the material flow models, but on the analytical results of the glass samples.

\section{INSTALLATION OF A NEW MELTER}

An alternative to the approach of melter flushing is to install a new melter in the Shielded Cells. This is a non-trivial job which would require additional time. The existing melter would still need to be flushed with nonradioactive material and then decoupled from the off-gas system, removed, and dispositioned. A new melter (one new melter has already been fabricated and is available) would then have to be baked to remove the residual water in the refractory. Nonradioactive testing would then be required to ensure that the system functions af intended. This approach would eliminate the concern of exceeding the NTS limits for TRU and RCRA metals due to contamination.

\section{CONCLUSIONS}

In order to meet the NTS WAC for the CST vitrification demonstration, the existing melter within the Shielded Cells must first be flushed with non-radioactive, non-hazardous glass. Due to the high levels of TRU and RCRA metals in the existing glass, $\sim 10$ melter volumes of material need to be processed to ensure acceptable TRU and RCRA metals levels. A strategy must be developed and implemented to provide the best opportunity for realizing this goal. This may include some periods or equilibration between pours, lowering and/or increasing the molten glass level in the melt pot, and use of different non-radioactive glasses. Sampling and analysis of the glass from the pour stream will be required such that the efficiency of the flushing process can be monitored. It is anticipated that the analytical feedback will provide direction to the actual approach. 
At a melter throughput of $\sim 1$ pound of glass per hour at $50 \%$ attainment ( 24 hours per day), flushing would take $\sim 20$ days. Additional steps in the protocol, such as equilibration, sample analysis, etc., will increase the overall time for melter flushing. Once an acceptable level of radionuclides and RCRA metals is obtained, there is still the risk, as discussed above, that pieces of glass or dried slurry could release, mix with the glass, and cause the waste glass to exceed NTS limits.

If a reduced scope of this task is realized, then the vitrified CST will be disposed of at SRS. In this case, the degree of flushing required will depend upon (1) SRS requirements for waste disposal and (2) task objectives for obtaining required data on the vitrified CST (i.e., the degree of contamination of the glass samples that can be tolerated). A separate report detailing these items will be issued.

\section{REFERENCES}

1. J. F. Walker, LMER Pretreatment, TTP OR1-6-WT-41, 1996.

2. W. F. Kinard, N. E. Bibler, C. J.Coleman, and R. A. Dewberry, Radiochemical Analyses for the Defense Waste Processing Facility Startup at the Savannah River Site, Journal of Radioanalytical and Nuclear Chemistry, Vol. 219, No.2, 1997.

\section{DISTRIBUTION}

M. K. Andrews, 773-A

N. E. Bibler, 773-A

D. A. Crowley, 773-43A

E. F. Duhn, 773-A

D. M. Ferrara, 773-43A

B. C. Ha, 773-43A

J. R. Harbour, 773-43A

E. W. Holtzscheiter, 773-A

L. F. Landon, 704-1T

M. J. Plodinec, 773-A

C. T. Randall, 704-T 